

\section{Shirkah}

Journal of Economics and Business

Vol. 3, No. 1, January-April 2018

ISSN: 2503-4235 (p); 2503-4243 (e)

\section{Editor in Chief}

Dwi Condro Triono

\section{Managing Editor}

Jasanta Peranginangin

\section{Editorial Boards}

Abdul Azim Islahi,

Islamic Economics Institute, King Abdulaziz University, Saudi Arabia

Abu Umar Faruq Ahmad,

UBD School of Business and Economics Universiti, Brunei Darussalam

Cedomir Nestorovic,

ESSEC Business School Asia Pacific, Singapore

Fitri Wulandari,

Faculty of Islamic Economics and Business, IAIN Surakarta, Indonesia Johan Fischer,

Department of Social Sciences and Business Roskilde Universitetscenter, Denmark Muhamed Zulkhibri,

Islamic Research and Training Institute, Islamic Development Bank, Saudi Arabia M. Kabir Hassan,

Department of Economics and Finance, University of New Orleans, United States Musa Asy'arie,

Faculty of Islamic Economics and Business, IAIN Surakarta, Indonesia

Nunung Nurul Hidayah,

Aston Business School, Aston University, Birmingham, United Kingdom

Saim Kayadibi,

Department of Economics, Kulliyyah of Economics and Management Science, International Islamic University Malaysia, Malaysia 
Shaikh M Ghazanfar,

Departement of Economics, University of Idaho, Russian Federation

Sigit S. Wibowo,

Department of Management, Faculty of Economics and Business, Universitas Indonesia, Indonesia

Vihang R. Errunza,

Desmarais Global Finance Research Centre, Desautels Faculty and Management, McGill University, Canada

\section{Assistant to Editor}

M. Endy Saputro

M. Zainal Anwar

Shirkah Journal of Economics and Business is a peer-reviewed journal published three times a year (January-April, May-August and September-December) by Faculty of Islamic Economics and Business, Institut Agama Islam Negeri (IAIN) Surakarta Central Java, Indonesia. The main objective of Shirkah is to offer an academic space of exchange ideas and initiate the increase number of qualified article produced by postgraduate students, practitioners and academicians.

\section{Editorial Office}

Ruang Jurnal Shirkah

Lantai Dasar, Sayap Barat, Fakultas Ekonomi dan Bisnis Islam, IAIN Surakarta

Jln. Pandawa No. 1, Kartasura, Sukoharjo, Jawa Tengah Kode Pos. 57168

Phone (+62271) 781516 Fax: (+62271)782336

E-mail: shirkahjournal@iainsurakarta.ac.id; shirkahiainsurakarta@gmail.com

Website: http://shirkah.or.id/ 


\section{Shirkah}

Journal of Economics and Business

Vol. 3, No. 1, January-April 2018

ISSN: 2503-4235 (p); 2503-4243 (e)

\section{Table of Contents}

\section{Articles}

Aqeel Akhtar

Fahad Ahmed Qureshi

Mubeen Butt

Laws of Collateral in Today's World in Islamic Perspective

Anton Bawono

Creative Economic Development of Pesantren

Dwi Umardani

Conventional Home Loan and Islamic Home Financing in

Comparative Perspective

Iha Haryani

Dian Riskarini

Tia Ichwani

Business Development Strategy Model of SMEs

through SWOT and EFE-IFE Analysis

Ika Yoga

Halal Emotional Attachment on Repurchase Intention

Anik

Iin Emy Prastiwi

Macro Economic Challenges and Third Party Funds of Islamic Commercial Banks in Indonesia 


\title{
Conventional Home Loan and Islamic Home Financing in Comparative Perspective
}

\author{
Dwi Umardani \\ Sekolah Tinggi Ilmu Ekonomi Rahmaniyah Sekayu, South Sumatera \\ umardani_sumsel@yahoo.com
}

\begin{abstract}
This article aims to comparatively discuss conventional home loan (Kredit Perumahan Rakyat/KPR) and Islamic home financing (Pembiayaan Pemilikan Rumah Syariat/PPRS), locating in Bank Central Asia (BCA) and Bank Syariah Mandiri (BSM). Qualitative narrative of formal procedural system of owning home of the mortgages critically analyzed aiming to get clear-cut the differences both loans. This paper confirms that BCA uses the interest system in providing mortgage (KPR) and does not concern on the use of the funds. BSM generally has implemented murabaha scheme (deferred payment sale). For the late paying installments, both banks have applied quite different procedure systems.
\end{abstract}

Keywords: mortgages, home loan, KPR, PPRS, penalty

\section{Introduction}

Arguably, the contracts available in a conventional and an Islamic bank are quite different. These different concepts reflect their respective mortgage products; the conventional bank named it as mortgage loan (Kredit Perumahan Rakyat/ KPR), and the Islamic bank with its Islamic mortgage financing (Pembiayaan Pemilikan Rumah Syariat/PPRS). The conventional bank offers the KPR to its costumers only by means of giving some loan with only one type of contract, and the costumers are obliged to return the "loan plus interest" (Fareed, Arsalan, \& Ayubi, 2017). Meanwhile the Islamic bank suggests the PPRS services to its costumers 
by giving them some financing with more various types of contracts suited to the costumers' needs (A. M. E. T. Ahmed, 2010). The customers are obliged to return the "cost plus margin" in murabahah and istishna', the "cost plus fee" in IMBT (ijarah muntahiyah bittamlik/ financial lease with purchase option) contract, the cost plus profit/loss sharing in MM (musharakah mutanaqisah) (Azcarya, 2012).

Unfortunately few customers are still unaware of the differences between those two products. Al-Salim (2009) shows that many people can not see the significant differences and some others judge that the products offered by Islamic banks are just the same as those offered by conventional banks. How significant is the difference between the operational applications of mortgage of a conventional bank and those from an Islamic bank. This article conveys the differences on the operational applications of KPR at (Bank Central Asia) BCA Ciputat and those of PPRS at BSM Ciputat. This article argues that BCA uses the interest system in providing mortgage (KPR) and does not concern on the use of the funds. BSM generally has implemented murabaha scheme (deferred payment sale). For the late paying installments, both banks have applied quite different procedure systems.

\section{Conventional and Islamic Financing}

Basically people may buy a house either by cash or credit, but since not all can afford to pay for it by cash, they can choose banks as an alternative such as utilizing the "mortgage loan" services (KPR) offered by conventional banks or utilizing the "Islamic mortgage financing" services (PPRS) offered by Islamic banks (Bian, Lin, \& Liu, 2018). Conventional banks in Indonesia actually offer joint mortgage loan to both customer (end user) and developer, and they have different terminologies for two mortgage loan products. For the customer, it is usually called KPR while 
for the developer it is commonly known as construction loan. However, this section would be limiting the discussion on the KPR. There are two types of KPR (Diponegoro, 2011): general KPR or 100\% KPR and indent KPR. The former refers to a type of mortgage loan product with the disbursement of KPR after the construction of the house is $100 \%$ complete. In this product, no special cooperation is needed because the bank will only assess the customer and the object of the transaction. The latter denotes a type of KPR in which the disbursement is done gradually and is highly dependent on the construction process of housing units. In this case, both customer and developer usually have already made a buying and selling transaction before the building is completed. Some banks do the first tranche of disbursement when the construction process reaches $10 \%$, or when the construction of house foundation is complete (Cipriani, Fostel, \& Houser, 2018).

There are few such things that need to be considered before using KPR services as the reputation of the bank, the credit limit, the KPR term, the bank extensive networks in facilitating all customer transactions, and last but not least, the interest rate system. Before using KPR services, usually customers will be notified about its prevailing interest rate system. Having understood about it, the customers are expected to have adequate knowledge to choose an interest rate system that suits their potentials even though in reality they are usually still confused in determining a proper one corresponding to their abilities (Kashif, Abdur Rehman, \& Pileliene, 2016).

As Peter mentions that there are two types of interest rate system in KPR, known as flat interest rate and effective interest rate (Peter, 2008). A flat interest rate is a cost charged by the bank to the debtor by calculating the overall rate all at once to be equally distributed for each month (Agyeman \& Carsamer, 2018). The following are general formulas commonly used to calculate the monthly loan installments plus interest. 
Interest $=$ Loan amount $\mathrm{x}$ interest rate $\mathrm{x}$ loan period (year)

Total loan $=$ Loan amount + interest

Installment per month $=$ Total loan : (loan period x 12 months)

Meanwhile effective interest rate is a cost based on the calculation of the real loan amount running, so that the amount of interest rate for each month will be different as well as the principal amount that should be paid even though the number of installments is fixed. This is due to the calculation of the interest factor that affects the interest amount of monthly installments. The calculation formulas are as follows:

Interest factor $=(1: \mathrm{K})-(1:(\mathrm{K}(1+\mathrm{K}) \mathrm{N})$

Installment per month $=$ Loan amount $:$ interest factor

$\mathrm{K}=$ Interest per month

$\mathrm{N}=$ Number of monthly installments

Both interest rate calculation methods have strengths and weaknesses, yet the latter (effective interest rate calculation method) is the most frequently used one. It is because the first factor, the debtors only need to pay for the interest amount in accordance with the rest of the loan amount that they still owe (Mugerman, Tzur, \& Jacobi, 2018). Automatically, both installment amount and interest that should be paid next will become smaller. The second one, the bank can prevent loss caused by the interest rate fluctuations as in the effective interest rate calculation, the first year interest rate is usually fixed, and then starting from the beginning of the second year, the interest rate may change following the bank policy which updated refers to the national prevailing interest rate.

It is a brief description of KPR system in conventional banking in Indonesia. Next, the writer will succinctly explain the PPRS system provided by Islamic banking considering that Indonesia is one of the countries with dual financial system in which both Islamic and conventional financial systems are equally permitted to operate side by side in accordance with their 
respective paradigms and characteristics (Harahap, 2012). Conversely, in PPRS, the types of contracts are quite diverse such as murabahah (deferred payment sale), ijara muntahiyah bittamlik (financial lease with purchase option), musharakah mutanaqisah (diminishing musharakah) and istishna' (purchase by order or manufacture) (Rivai, Veithzal, 2008). With a wide variety of contracts available for PPRS, customers have more alternatives to choose the one that matches their respective needs.

The first contract type for PPRS is murabahah (deferred payment sale). It is a Sales and Purchase Agreement (SPA) between an Islamic bank and its customers (Abdul-Rahman, 2014). In this case, the bank purchasesan item required by the customer sand sells it to them at costplus margin that the bank and its customers agree. With this type of contract, customers cansoonhave a homealong with its risks and obligations, so they can immediately take advantage of the home according to their needs (S. S. Mohd Yusof, Oseni, \& Hasan, 2016). The customerobligationafterthatis to pay offthe agreedpricewithina specific time,and the payment is usuallycompletedby way ofinstallments.

During the installments, the home prices do not change or are fixed so that the customers do not have to worry about the interest rate changes in the market. Consequently, the bank has fixed income during installments. It will not get more profit despite the rising of market interest rates, and vice versa (it will not suffer a loss in spite of the falling interest rates in the market) (Adelino, Schoar, \& Severino, 2018). Nevertheless, the bank is likely to face losses in the form of bad credit if its customers cannot pay off the remaining installments. However, if it really happens; usually the bank will ask its customers to sell their homes to pay off the remaining unpaid installments, while the rest of the proceeds belong to those customers.

In addition to the murabahah contract, Islamic banks in Indonesia also have ijarah muntahiyah bittamlik contract (financial lease with purchase 
option) or IMBT. This second type of contract for PPRS is a kind of a mix between Sales and Purchase Agreement (SPA) and Lease Agreement, or it is more precisely called the lease contract with the possession ending in the hands of the lessee. Thus with IMBT, customers will obtain the home that they lease from the Islamic bank at the end of the period with the pledge ( $\left.w a^{\prime} a d\right)$ of "transferring the ownership to the lessee", so after the installment period is over, the bank will donate or sell the home to the lessee (Rahman, 2010).

IMBT is the right solution for customers who want to own a home at the end of the installment period. With this type of contract, customers will not bear the risks of ownership that may occur during the contract period such as loss, damage, or decline in selling price. However, since the home is still owned by the bank until the end of the contract period, it may adjust the rent price in accordance with the increase in the market interest rates (Amin, Amin, Rahim, Rahman, \& Abdul Razak, 2014). In circumstances where the customers can no longer afford to pay the home rent, the bank can ask them to occupy a more affordable one, and rent out that home to other party.

The third type of contract for PPRS is musharakah mutanaqisahor MM (diminishing musharakah). Musharakah in arabic means "partnership"; a diminishing musharakah is a diminishing partnership, in the sense that a home buyer and his/her bank are partners in the purchase of the home (Asadov, Muhamad Sori, Mohamad Ramadilli, Anwer, \& Shamsudheen, 2018). The MM contract generally provides for the home buyer to contribute a deposit, while the bank pays the rest, and the two become co-owners of the home. The home buyer lives in the house, paying rent to the bank as well as regular scheduled purchases of "units" of the bank's share of the house. As the bank's ownership decreases/diminishes, the rent decreases accordingly, until the home buyer has bought out the bank 
ownership portion and owns the house outright (R. Mohd Yusof, Bahlous, \& Haniffa, 2016).

$\mathrm{MM}$ is a contract derived from general musharakah contract. It means that a joint contract of two or more sides on a certain business where each side contributes some fund or expertise with the agreement that the risks will be borne together and the profit will be shared accordingly. In other words, it is a certain agreement among shareholders on a certain business activity, and the profit will be given to each shareholder based on the agreed percentage. If losses happen, they are taken by shareholders based on the agreed capital percentage. Further, businessdictionary.com defines musharakah as an "Islamic principle that is applied to joint ventures where interest is not charged by the creditor of the loan, instead an agreement is made between the creditor and the buyer as to the share the creditor will get from the profit made from the venture. This also applies to any losses made in the business".

According to Smolo and Edib MM is one of syariah contracts that are appropriate to PPRS and are also generally used for other kinds of Islamic financing.

"The $\mathrm{MM}$ is an equity-based financing technique available for Islamic banks. This model can be easily applied in various sectors such as housing projects, financing car purchases, financing working materials and equipments, financing business projects, etc. It could even be used for alleviating poverty through microfinancing or for financing micro- and mediumsize enterprises. It has been successfully implemented for home financing in Canada, the USA, the UK, Australia, Middle East, Sudan, Pakistan, etc" (Smolo, Edib, 2011).

Using this contract, the home belongs to both bank and customer based on their portion. Within contract period the customer makes 
purchasing ownership of capital portion from the bank until the ownership portion is $100 \%$ owned by the customer and is moved to him. As long as period of the contract the home is owned jointly by both parties, and it may be rented out to a third party or it can be leased to the customer him/ herself (Mohamed Imtiyaz, Kassim, \& Harun, 2017).

However, since the customer is someone in this case wishing to own the home, usually the customer him/herself is the one who rents it. The rental fee will be fairly shared to both parties in accordance with their respective portions. Consequently, with this contract the home is owned together once the contract is approved, so that rights, responsibilities, as well as risks that may occur shall be taken together. For prudence, they can mitigate risks such as damage, fire, etc. by way of insuring the home. Meanwhile, if the home selling price is declining in the market, the risk will be equally shared by both parties (Aboulaich \& Yachou, 2016). By circumstance where the customer is unable to pay off the share of home ownership, both parties can sell the home to a third party and divide the proceeds of the sale according to their respective portions.

The last contract of PPRS is istishna' (purchase by order or manufacture). It is a Sales and Purchase Agreement (SPA) by means of ordering an item with the criteria and conditions as agreed upon by the buyer. In PPRS context, this contract is typically chosen by a customer (the buyer) who wants to own a dream home that meets the required specifications, so in this case the bank will act as the seller (Abdul-Rahman, 2014). The customer merely needs to pay the bank to build that home, and the payment is made in installments. As a matter of fact, the bank is not the one that builds that specially ordered-home, yet it cooperates with a contractor asking this specialist to build it for the bank. Consequently, there are two joint agreements referred to as "parallel istishna"; firstly between the bank and its customer, then between the bank and the contractor. 
The contract agreement between the bank and its customer must be separated from that between the bank and the contractor. Thus the bank is obliged to fulfill what the customer specifically wants with the home ordered. Since the bank is responsible for that order, if it does not comply with the specifications that have been agreed, the customer has right to cancel the contract, and then the bank must refund all the payments that have been made by the customer. With this scheme, customer can not directly own the home but has to wait for quite some time until the construction is ready. If the customer is unable to pay off the installments, he/she can sell the home and gives the rightful portion of the proceeds to the bank first of all, and he/she can have the rest if there are still some remaining proceeds of the home sale.

Those are the four types of contracts that are well known in the world of Islamic financing, and that have also been popular in Indonesia since 1992. However, Bitor and Farhat also mentioned four types of contracts with similar understanding but some have rather different terminologies. Those contracts are (1). Musharakah muntahiyah bit-tamlik contract (2). Murabahah lil-amir bisyira' contract (3). Ijarah ma'al-wa'di bit-tamalluk contract, and (4). Istishna' contract. Again, these terminologies appear to be rather different yet principally have the same ideas as the other four types previously described, and all of them are applicable to any Islamic mortgage financing (Bitor, 2009).

\section{Two Different Mortgages}

Bank Central Asia (BCA) uses the Mortgage Loan (KPR) terminology instead of Mortgage Financing (PPR) terminology to finance mortgage to its customers. BCA does not distinguish whether this product is "lending" or "financing", as both "lending" and "financing" are all the same to BCA in which it lends a sum of money plus interest to 
customers, and with that loan the customers are obliged to return the cost plus interest. Thus the relationship between BCA and its customers is a creditor-debtor relationship where BCA as the creditor has right of getting back the loan including the interest while its customers, as the debtors, have the obligation to pay off the cost plus interest with a certain amount agreed upon at the beginning of the contract (Rafay \& Farid, 2017).

The interest rate used by BCA for KPR is effective interest rate. It is an interest rate based on the calculation of the real loan amount running, so that the amount of interest rate for each month will be different as well as the principal amount that should be paid even though the number of installments is fixed (Ramadani, Dana, Ratten, \& Tahiri, 2015). This is due to the calculation of the interest factor, that affects the interest amount of monthly installments. BCA generally provides KPR with three programs: KPR BCA (regular), KPR BCA Refinancing and KPR BCA Xtra.

KPR BCA (regular) is a financing facility program, for a (new or used) home/building ownership, offered by BCA by means of lending a sum of money to its customers who will be required to return the cost plus interest according to the agreement made at the beginning of the contract. KPR BCA Refinancing is a refinancing facility program with collateral (it can be a home or building). This program provides for the customers requiring some loan such as for renovating a home, buying a new home, or financing other various needs. Like the program of KPR BCA (regular), KPR BCA Refinancing program also provides some loan for the customers, and the customers are required to return the loan principal and interest. This financing is usually issued in cash and immediately transferred to the customers' accounts.

The difference between the programs of KPR BCA and KPR BCA Refinancing is that KPR BCA is offered to any customer who wants to own a home. However, those who take this program are usually the customers 
that have no home at all. Since the bank directly allocates the loan to pay for the home, the customers are consequently not able to make use of that loan for other purposes. Meanwhile, KPR BCA Refinancing must only be given to the customers who have already owned a home or property as the collateral to guarantee that they will repay the loan. Somehow, since the customers receive that loan in cash, some customers now and then use it for other purposes other than for a new home purchase.

The last program is KPR BCA Xtra. It is a program of home/building financing service. Basically, it has the same general lending concept; it also provides some loan, whereas the customers are obliged to return it plus interest. Instead, compared to KPR BCA and KPR BCA Refinancing, this program provides more multiple benefits. Customers may determine their own amount of monthly installments corresponding to their affordability. Under the circumstances where they are in such need of some cash, the instalments deposited in certain months can be withdrawn as much as the predetermined plafond.

The three BCA lending programs above are usually given along with the Fix and Cap program that will temporarily benefit the customers by providing an absolute certainty on interest rates for, a relatively long period, five years. Fix period is the period in which the interest rates are fixedly set early at the beginning of the contract. In other words, the debtors have a fixed interest rate for the first three years. Meanwhile, Cap period is a period in which maximum interest rates are set and imposed two years early after the Fix period ends. Soon after the Fix \& Cap period is over, the interest rates prevailing are the "floating rate". BCA mortgage loan program has its own advantages, and customers can select one of those three alternatives that may best address their needs and affordabilities. Although the Fix and Cap program offered along with all the products aims to give the certainty of interest rate, the customers can still get the loan even without taking it. 
Why BSM is using the terminology of "mortgage financing" (PPR/ Pembiayaan Pemilikan Rumah) instead of "mortgage loan" (Kredit Pemilikan Rumah-KPR) or "Islamic Mortgage Loan" (Kredit Pemilikan Rumah Syariah-KPRS) will be explained in the following paragraph. The word "loan" according to many Islamic economists is a word derived from Arabic qaradha which means "lend" or "lending some money on the basis of trust" (it is not derived from Latin "credo" meaning "I believe" or "I trust" as claimed by many conventional economists). A lending and borrowing transaction in Islam, or often referred to as "qard", is a normal lending and borrowing deal from which the lenders are not allowed to take any compensation (Syafi'i, 2012).

In the terms of providing home ownership program, BSM is absolutely not giving a loan (qard) but providing some financing to its customers in the hope of getting some profit because financing is a 'commercial' activity of managing money, debt, credit, and investment so that the word "financing" is more representative than the word "loan" to the mortgage product provided by BSM, and therefore BSM keeps using "PPR" terminology (some Islamic banks are still consistent using the "KPRS" terminology considering that most people are away more familiar with it (Hussain \& Ali, 2017) including financial assets such as shares, unit trusts, current accounts and investment accounts which are Sharīah non-compliant. With the four contracts explained earlier, BSM treats its customers as partners since those contract-agreements are enabling the two parties to cooperate.

Among the four contracts possibly used for the Islamic mortgage financing above, murabahah (deferred payment sale) is the one generally used by BSM (Karim, 2007). It means a sales and purchase agreement (bai) between BSM and its customers where the price comprises at cost plus margin (ribh) agreed by both parties. In this regard BSM may act as 
a seller or buyer; as a seller if BSM sells the home to its customers and as a buyer if BSM purchases the home from the developer and directly sells it to the customers. The transaction mechanism is that after the customers find a home through a developer, they can come to BSM and apply for PPR using murabahah contract (Haris, n.d.). Next, BSM meets the developer and purchases that home in cash and then sells it to the customers. The last mechanism is that the customers can pay off the financing by means of installments with the cost plus margin mutually agreed according to what is written in the contract.

For example, a customer takes the PPR service of BSM for Rp. 200.000.000,- on January 1, 2012. After assessing the proposal (application), BSM makes a contract telling that (1) the customer must pay off the down payment for $20 \%$ (Rp. 40.000.000) out of the proposed amount of loan to the developer, (2) the customer should agree with the $9.5 \%$ of determined margin per year, (3) and the customer is supposed to settle the ten year installments (120 months). The installment calculation can be shown as follows:

Home price

Rp. 200.000.000

Urbun (down payment)

Rp. 40.000 .000

PPR amount

$$
\begin{aligned}
& \text { Rp. } 200.000 .000 \\
& \text { Rp. } 40.000 .000 \\
& \hline \text { Rp. } 160.000 .000
\end{aligned}
$$

Margin 
9.5\% x 10 x Rp. 160.000 .000

Rp. 152.000 .000

Margin per month

$$
\begin{aligned}
& \frac{\text { Rp. } 152 \cdot 000 \cdot 000}{120} \\
& =\text { Rp. 1.266.666,67 }
\end{aligned}
$$

Installment per year

$$
\begin{gathered}
\frac{(\cos \mathrm{x} \text { margin } \mathrm{x} \text { period of time })+\text { cost }}{\text { Duration }} \\
\frac{(\text { Rp. } 160.000 .000 \times 9,5 \% \times 10)+\text { Rp. } 160.000 .000}{10} \\
=\text { Rp. } 31.200 .000
\end{gathered}
$$

Installment per month

$$
\begin{aligned}
& \frac{\text { Rp. 31.200.000 }}{12} \\
&=\text { Rp. } 2.600 .000
\end{aligned}
$$

BSM once offered PPR product through four programs, yet only three programs are used now, namely BSM Griya Financing, BSM Griya Optima Financing, and BSM Subsidized Griya Financing. BSM Griya Financing is a short, medium, or long term financing for procurement of a house (consumer) either new or old unit in a developer or non-developer area using the murabahah scheme. BSM Griya Optima Financing is a house ownership financing with extra benefits of additional fund to be 
withdrawn by the customers at specified dates provided that the collateral value covers the total financing and is subject to the customers' Debt to Service Ratio (DSR) adequacy. The financing allotment qualified for Griya BSM Optima Financing is procurement of a certified residential house (consumer) either a new or old house at a developer area or non-developer area and is feasible for the customers to add a financing facility for covering other consumer needs pursuant to the DSR and collateral adequacy for covering the total financing. BSM Subsidized Griya Financing is a financing facility for procurement of the Simple Healthy House (RS Sehat/RSH) from a developer company with the government subsidy to build such Simple Healthy category houses (Bian et al., 2018).

Having carefully regarded the previous explanation of the contracts used by BCA and BSM, the writer discovers many significant differences. Those can be seen in the terms of the product naming, the customer positioning during the contract period, and the contracts used. In the terms of product naming; BCA is using KPR and BSM is using PPR. The customer positioning; BCA treats its customers as debtors, while BSM treats them as partners. The contracts used; BCA is using lending and borrowing contract, while BSM is using murabahah.

The difference in the terms of KPR and PPR terminology is due to the perception of the words "loan" and "financing". BCA as a conventional bank is not concerned about the term by either "loan" or "financing" in providing mortgage since both "loan" and "financing" have the same understanding for BCA (Rahman, 2010). It is lending sum of money plus interest to its customers. Meanwhile, BSM as an Islamic bank questions the term "loan" and "financing" in PPR as BSM has different treatments between "loan" and "financing"; "loan" is only used for an ordinary lending and borrowing contract which is not permitting the lender to take out any advantage, while "financing "is a joint contract that allows the lender to take some profit (Abdul-Rahman, 2014). 
With the word "loan" in the sense of lending and borrowing, BCA treats its customers as debtors so that the relationship between the bank and the customers is the creditor and debtor relationship. Meanwhile, BSM with the word "financing", uses murabahah contract treats its customers as partners. From the 'contract' point of view, BCA as a conventional bank doesn't need to adjust it. BCA is only using one type of contract for general financing purposes. It is a 'lending and borrowing contract' by way of lending specific amount of money to its customers for a specific period of time, and the customers are obliged to return it along with the interest that has been agreed upon early at the beginning of the contract. On the other hand, BSM as an Islamic bank obviously has more than one contract since BSM always customizes its contracts based on specific purposes and in accordance with Islamic principles. Consequently, each customized contract also has its own mechanism of financing and returning schemes.

Thus, although the contract made by BCA aims for home ownership purpose, the customers may use the loan for other than that. The point is that as long as they can afford to pay the monthly installments, they can use the loan through the contract no matter what the purpose is (Mohamed Imtiyaz et al., 2017). For example, for business purpose, they can use the loan to finance their working capital. It is very likely to occur in BCA Refinancing program since the loan is usually issued in cash and immediately transferred to the customers' accounts.

On the other side, BSM has the consistency with all its contracts. For example, if the customers are willing to own a home and they decide to take murabahah as the chosen contract for home ownership purpose, they are not supposed to use that financing for other than a home purchase. Should they break the regulation for instance using the money for business purpose, they are in violation of their own contract (Arifin, 1998). That is because business financing can not be addressed by murabahah contract, but 
it must use its own possible contracts such as musharakah or mudharabah. That is why if the fund is used to finance other than it is supposed to be, the customers are considered to have committed an offense (Haron, 2009). Consequently, with this rule the disbursement mechanism is that BSM tends to remit the fund directly to the developer or the seller as the bank also needs that home for the official collateral (Arthesa, 2006).

\section{Paying Late and Before Maturity Date}

BCA requires its customers to pay the installments on time without having to consider the conditions whether they do the late payment on purpose or not, whether there is an accident or not, and so on. Hence, BCA will apply a penalty fee to the customers paying late the monthly installments since BCA assumes that it has played its part well having fulfilled its obligations by lending the agreed sum of money to its customers therefore BCA also assumes that it is rightful to apply the penalty fee to the customers with such condition. The loan is bound by 'interest covenant' so that the customers must pay the installments at cost plus interest (Tomura, 2018). Consequently, by circumstance where the customers are unable to meet their obligations by paying the installments on time, BCA will impose penalty fee which is considered as income.

If the delay lasts for several months in a row, and BCA has already sent Warning Letter to the customers, yet they still can not keep up the repayments, they risk losing their homes as BCA will do thefore closure. Once the home is seized and sold, BCA can take its rightful proceeds of sale along with the administrative expenses, while the rest of the proceeds remain to the customers. Unlike BCA, if the installments are overdue or later than the date on which the customers should have paid, BSM will perform anticipatory steps such as issuing Warning Letter to the customers 
and conducting an evaluation on the factors of delay cases (Kashif et al., 2016).

If the customers have a good will and understand their obligations well to pay the installments on time, but they can not keep up the repayments due to some unwanted insidents such as experiencing a decline in sales, getting laid off from work, or having a disaster etc., BSM will give them waivers and alternatives in the form of the payment grace period (F. Ahmed, Haque, Abdullah, \& Razali, 2017) Islamic brand identity and personality, haram-halal, Makhru, and devotion to God. Fundamentally it is Islamic value based brand image and equity development concept which is different from a platform of building image and equity from the contemporary ethical marketing. Positive customer-based brand equity entices consumers to buy products or service and the vice versa. Shariah-compliant brand image is a different set of dimensions like brand equity as supported by Shariah-law, whereas in the conventional brand knowledge, favorableness is considered as an important dimension; that is, only brand image as a main element of knowledge is conceptualized in this model because Islam does not priotize personal favorableness violating Shariah law. However, if the customers have no intention of fulfilling their obligations to pay the installments on time, but in fact they can afford to settle the monthly payments and their business does not suffer from losses or disaster, BSM will teach a lesson by imposing a penalty fee on them as the punishment for their negligence, so that they do not do it again.

The penalty fee is charged to the customers as cost arrears meaning a cost charged due to the customer negligence in fulfilling their obligations to the bank (Agyeman \& Carsamer, 2018). The amount of money for the penalty fee is established by the internal bank regulation. BSM does not recognize the arrears as incomes but regards them as benevolent loans (qardhul hasan / It is a loan that truly does not compensate the creditor for the time value of money). 
Somehow, if those steps have been taken, and the bad credit still occures as the homeowners can not keep up the payments, BSM will conduct a foreclosure on that home (Tomura, 2018). After the home is auctioned and sold to a third party, the proceeds of sale including the unpaid amount of the installment plus administrative cost will be given to BSM, while the rest of proceeds belong to the customers. It can be inferred that BCA and BSM differently treat their customers with bad credit or who can not keep up the payments of their monthly installments (Bian et al., 2018). BCA applies a penalty fee to the customers with late installment payment regardless of their good intention to settle the bad credit, and that fee is recognized as the bank income. Meanwhile BSM only applies a penalty fee to the customers proven negligent with the obligations that they ought to fulfil to the bank, and BSM considers that penalty fee as the arrears, and does not recognize it as incomes but regards it as a benevolent loan (qardhul hasan).

In the case wherethe customers want topay off the remaining KPR installments before maturity, BCA distinguishes the customers into two conditions: the customers following one of the three available programs, KPRBCA, KPRBCA Refinancing, or KPRBCAXtra, plus their Fix and Cap program or the customers choosing KPR, but the payment method used is floatinginterest rate from the beginning of the payment period. To the customers following one of the three available programs, KPRBCA, KPRBCA Refinancing, or KPRBCAXtra, plus their Fix and Cap program, or those are classified into condition one, BCA applies a penalty fee that is taken from the principalloan of the remaining monthly installments and is recognized as income (Mugerman et al., 2018).

Meanwhile, to the customers choosing KPR, but the payment method used is floating interest rate from the beginning of the payment period, or those classified into the latter condition, BCA does not impose any penalty fee (Tomura, 2018). BSM somehow has a different attitude 
towards the customers who want to pay off the remaining amount before the due date. In this regard, BSM will not apply a penalty fee to its customers, yet if the customers ask for a discount, BSM may consider the proposal as long as there was no agreement at the beginning of the transaction.

It can be concluded that there are different treatments between BCA and BSM in dealing with the customers who want to settle their installments prior to maturity. BCA will impose a penalty fee to the customers following one of the among three programs; KPR BCA, KPR BCA Refinancing, or KPR BCA Xtra given along with the Fix and Cap program, while to the customers choosing KPR but the payment method used is floating interest rate from the early payment period, BCA will not apply any penalty fee. Meanwhile, BSM does not impose any penalty fee to the customers willing to pay off their remaining installments before maturity. In other words, the customers are given the options to choose whether paying off the installments until the end of the agreed period or early before the due date.

\section{Conclusion}

The two banks have a sharp distinction attitude in the case where the customers want to pay off the remaining loan before maturity. BCA will impose a penalty fee to the customers following one of the among three programs; KPR BCA, KPR BCA Refinancing, or KPR BCA Xtra given along with the Fix and Cap program, while to the customers choosing KPR but the payment method used is floating interest rate from the early payment period, BCA will not apply any penalty fee. Meanwhile, BSM does not impose any penalty fee to the customers willing to pay off the remaining installments before the due date. 
After knowing the competition between KPR on BCA and PPRS on BSM, the two companies should be further enhancing their competitiveness. Each company should be able to provide/give an adequate education and information to their customers particularly who are willing to apply for KPR or PPRS. Each of the two companies may improve their socialization especially for the home ownership financing program in cooperation directly with all stakeholders such as developers, academics, and customers either by way of providing seminars, counseling, or interactive dialogue through print and electronic media. The customers, going to apply for either KPR or PPRS, should first learn the applicable system to both BCA and BSM so that they will actually understand and next they can choose the home ownership financing in accordance with their desire.

Having carefully discussed on the operational applications of KPR from PT. Bank Central Asia Tbk and PPRS from PT. Bank Syariah Mandiri, as the closing remarks the writer will give conclusions and suggestions in the hope that this research may be of benefit to the writer himself, the companies concerned, and the public. Mortgage Loan (KPR) or Islamic Mortgage Financing (PPRS) is one of the bank's products offered to the customers who want to own a home. With this product both bank and customers are equally benefited as bank will benefit from income received in the form of the excess/difference in cost of the home buying and selling price to its customers. Meanwhile, the product is also benefiting the customers. Since despite they currently lack of funding, they can still have a home by way of applying for either KPR or PPRS to the bank.

In addition to the conventional bank, the Islamic bank also provides home ownership financing. With the increase number of home ownership financing options, the customers have more alternatives to determine which banks are matching their need. From the explanation above, at 
least the customers can get further information of the characteristics from $\mathrm{BCA}$ and BSM in the terms of home ownership financing. The principle of contract agreement for each BCA and BSM in providing mortgage financing is different. BCA is using "loan contract" in which the loan is regarded as debt that must be repaid by the customers within a specified time with an additional interest.

BSM somehow has a different pattern for every financing case. Generally, in the terms of PPRS, BSM is using murabahah contract, and it is classified as a sales and purchase agreement (bai ) so that the bank's profit is calculated using the principle of margin. The installment method used between the two banks is distinctly different. BCA offers Fix and Cap program that will temporarily benefit the customers by providing an absolute certainty on interest rates for, a relatively long period, five years. Soon after the Fix \& Cap period is over, the interest rates prevailing are the "floating rate" so the amount of the installments is subject to change at any time. Meanwhile, using murabahah contract, BSM installments are calculated using a flat margin system and they will always be fixed until the end of the repayment period.

There are obvious distinctions between the two banks in the case where the customers are paying late the installments. BCA will impose penalty fee to the customers overdue to pay the installments (later than the date on which they should have been paid) regardless whether the customers have a good faith to repay the installments or not, and it is recognized as the bank income. Meanwhile, BSM will only apply penalty fee towards its customers proven negligent in meeting their obligations to the bank, and the bank does not recognize the fee as income and it will be used as a benevolent loan (qardhul hasan). 


\section{References}

Abdul-Rahman, Y. (2014). The Art of RF (Riba-Free) Islamic Banking and Finance: Tools and Techniques for Community-Based Banking. John Wiley \& Sons.

Aboulaich, R., \& Yachou, N. (2016). Home financing through modified diminishing partnership. International Journal of Applied Business and Economic Research, 14(11), 7839-7861.

Adelino, M., Schoar, A., \& Severino, F. (2018). The role of housing and mortgage markets in the financial crisis. Annual Review of Financial Economics, 10, 25-41. https://doi.org/10.1146/annurevfinancial-110217-023036

Agyeman, E. A., \& Carsamer, E. (2018). Pentecostalism and the spirit of entrepreneurship in Ghana: the case of Maame Sarah prayer camp in Ghana. Journal of Contemporary African Studies, 36(3), 303-318. https://doi.org/10.1080/02589001.2018.1502416

Ahmed, A. M. E. T. (2010). Islamic banking: How to manage risk and improve profitability (Vol. 640). John Wiley \& Sons.

Ahmed, F., Haque, A., Abdullah, K., \& Razali, S. S. (2017). Customer-based brand equity model for the Shariah-compliant tourism: A conceptual model from the Muslim tourists' perspective. Advanced Science Letters, 23(9), 8541-8546. https://doi.org/10.1166/asl.2017.9925

Al-Salim, F. H. (2009). Islamic Financial Product Innovation. International Journal of Islamic and Middle Eastern Finance and Management.

Amin, H., Amin, H., Rahim, A., Rahman, A., \& Abdul Razak, D. (2014). Consumer acceptance of islamic home financing. International Journal of Housing Markets and Analysis, 7(3), 307-332. https://doi. org/10.1108/IJHMA-12-2012-0063

Arifin, Z. (1998). Pasar Uang dan Valuta Asing Berbasis Syariah, Paper presented at Bank Indonesia, Jakarta 21 Desember. 
Arthesa, A. \& H., Edia. (2006). Bank dan Lembaga Keuangan Bukan Bank, PT. Indeks.

Asadov, A., Muhamad Sori, Z. B., Mohamad Ramadilli, S., Anwer, Z., \& Shamsudheen, S. V. (2018). Musharakah Mutanaqisah homefinancing: issues in practice. Journal of Islamic Accounting and Business Research, 9(1), 91-103. https://doi.org/10.1108/JIABR-08-2015-0036

Azcarya. (2012). Akad dan Produk Bank Syariah. Jakarta: Rajawali.

Bian, X., Lin, Z., \& Liu, Y. (2018). House price, loan-to-value ratio and credit risk. Journal of Banking and Finance, 92, 1-12. https://doi. org/10.1016/j.jbankfin.2018.04.006

Bitor, M. L. and F., Muna Khalid. (2009). Aliyatut Tamwil Al-Aqori FilMasorifil Islamiyah.

Cipriani, M., Fostel, A., \& Houser, D. (2018). Collateral Constraints and the Law of One Price: An Experiment. Journal of Finance, 73(6), 2757-2786. https://doi.org/10.1111/jofi.12722

Diponegoro, A. (2011). Raja Bisnis Properti Mega Profit No.2 di Indonesia. Jakarta: PT. Buku Seru.

Fareed, S., Arsalan, T., \& Ayubi, S. (2017). Bank deals with liquidity: The micro and macroeconomic determinants approach evidence from Pakistan (Vol. 2017-January, pp. 1073-1086). Presented at the Proceedings of the 30th International Business Information Management Association Conference, IBIMA 2017 - Vision 2020: Sustainable Economic development, Innovation Management, and Global Growth.

Harahap, S. S. (2012). Research Methodology: An Islamic Perspective. Jakarta. Haris, H. (n.d.). Pembiayaan Kepemilikan Rumah, Sebuah Inovasi Pembiayaan Perbankan syariah. Jurnal Ekonomi Islam.

Haron, S. and A., Wan Nursofiza Wan. (2009). Islamic Finance and Banking System Philosophies, Principles, and Practices. Malaysia: Mc Graw Hill Education. 
Hussain, L., \& Ali, M. M. (2017). Sharī'ah non-compliant assets as rahn (pledge) in Islamic banking products: a fiqhī perspective. ISRA International Journal of Islamic Finance, 9(2), 196-199. https://doi. org/10.1108/IJIF-08-2017-0018

Karim, A. A. (2007). Bank Islam Analisis Figh dan Keuangan. Jakarta: Rajawali Press.

Kashif, M., Abdur Rehman, M., \& Pileliene, L. (2016). Customer perceived service quality and loyalty in Islamic banks. TQM Journal, 28(1), 62-78. https://doi.org/10.1108/TQM-01-2014-0006

Kasmir. (2006). Manajemen Perbankan. Jakarta: Rajawali Press.

Kasmir. (2012). Bank dan Lembaga Keuangan Lainya. Jakarta: Rajawali Press.

M. Syafi'I, A. (2012). Bank Syariah dari Teori ke Praktik. Jakarta: Gema Insani Press.

Mohamed Imtiyaz, M. N., Kassim, S., \& Harun, N. Z. (2017). Perceived fairness in islamic home financing: Comparison between Al-Bay' Bithaman Ajil and Musharakah Mutanaqisah partnership contracts. Planning Malaysia, 15(4), 35-44.

Mohd Yusof, R., Bahlous, M., \& Haniffa, R. (2016). Rental rate as an alternative pricing for Islamic home financing: An empirical investigation on the UK Market. International Journal of Housing Markets and Analysis, 9(4), 601-626. https://doi.org/10.1108/ IJHMA-10-2015-0063

Mohd Yusof, S. S., Oseni, U. A., \& Hasan, R. (2016). Abandoned housing projects, legal risks and islamic finance legal documentation. Al-Shajarah, 21(Specialissue), 283-305.

Mugerman, Y., Tzur, J., \& Jacobi, A. (2018). Mortgage Loans and Bank Risk Taking: Finding the Risk Sweet Spot. Quarterly Journal of Finance, 8(4). https://doi.org/10.1142/S2010139218400086 
Peter. (2008). Perbandingan Perhitungan Angsuran KPR Konvensional dengan KPR Syari'ah. Jurnal Manajemen Maranatha.

Rafay, A., \& Farid, S. (2017). Dynamic relationship between islamic banking system and real economic activity: Evidence from Pakistan. Journal of King Abdulaziz University, Islamic Economics, 30(2), 97116. https://doi.org/10.4197/Islec.30-2.10

Rahman, Y. A. (2010). The art of Islamic banking and finance. Wiley.

Ramadani, V., Dana, L.-P., Ratten, V., \& Tahiri, S. (2015). The context of Islamic entrepreneurship and business: Concept, principles and perspectives. International Journal of Business and Globalisation, 15(3), 244-261. https://doi.org/10.1504/IJBG.2015.071906

Rivai, Veithzal, V., Andria Permata. (2008). Islamic Financial Management. Jakarta. Jakarta: Rajawali Press.

Smolo, Edib, H., M. Kabir. (2011). The potentials of musharakah mutanaqisah for Islamic housing finance. International Journal of Islamic and Middle Eastern Finance and Management.

Tomura, H. (2018). Payment instruments and collateral in the interbank payment system. Journal of Economic Theory, 178, 82-104. https:// doi.org/10.1016/j.jet.2018.08.008

Wiyarti, M. S. and M., Sutapa. (2007). Sosiologi. Surakarta: UNS Press. 


\section{Shirkah Author Guidelines}

Shirkah currently offers two routes to submit manuscripts. We highly recommend to submit the articles which are made using OJS (Open Journal System). Feel free register as author soon through visiting http:// shirkah.or.id/index.php/home/user/register. The authors may directly send their manuscripts, along with their resume, to shirkahiainsurakarta@ gmail.com. Please prepare your manuscripts, using following guidelines:

1. Manuscript must be written in English. Submitted articles should not have been published or be under review for publication with another journal.

2. Manuscript's length is about $15-20$ pages, typed in one-half spaced on A4-paper size.

3. Manuscript must include an $150-200$ word abstract and keywords.

4. Manuscript must be arranged as follows: Title, Name of Author, E-mail address, Abstract, Keywords, Introduction (including method if any), Discussion, Conclusion, References.

5. Manuscript's titles not more than ten words.

6. Manuscript must be submitted in Microsoft Word or RTF.

7. Arabic words should be transliterated according to the style of International Journal of Middle Eastern Studies.

8. Manuscript references are preferably derived from the up-to-date references.

9. The author's resume should be submitted separately, consisting of at least full name, institutional address, phone number, areas of studies, and recent publications (if any).

10. Shirkab use APA Style 6th edition (2010) as reference format writing. We suggest the use of a reference manager software such as Mendeley, Zotero, and Endnote at templating the citation style. APA Style to be used is as follows: 


\section{Book with single author}

Swann, G. M. Peter. (2014). The Economics of Innovation an Introduction. Cheltenhum \& Northampton: Edward Elgar.

in-text citation: (Swann, 2014)

\section{Articles in reference books}

Alatas, S. F. (2006). Islam and the Science of Economics in Abu Rabi', I.M. The Blackwell Companion to Contemporary Islamic Thought. USA: Willey-Blackwell (pp. 587-606).

in text citation: (Alatas, 2006)

\section{E-Book}

Hackett, Rosalind (2007). "Religous Dimentions of War and Peace: Introduction.” Dalam Gerrie ter Haar dan Yoshio Tsuruoka (Ed.), Religion and Society: An Agenda for the 21st Century (h. 3-6). Retrieved from http:// brill.nl.

in text citation: (Hackett, 2006)

\section{Master's thesis, from a commercial database}

McNieI, D. S. (2006). Meaning through narrative: A personal narrative discussing growing up with an alcoholic mother (Master's thesis). Available from ProQuest Dissertations and Theses database. (UMI No. 1434728)

in text citation: (Mc Niel, 2006)

\section{Doctoral dissertation, from an institutional database}

Adams, R. J. (1973). Building a foundation for evaluation of instruction in higher education and continuing education (Doctoral dissertation). Retrieved from http://www.ohiolink.edu/etd/

in text citation: (Adams, 1973) 


\section{Doctoral dissertation, from the web}

Bruckman, A. (1997). MOOSE Crossing: Construction, community, and learning in a networked virtual world for kids (Doctoral dissertation, Massachusetts Institute of Technology). Retrieved from http:/www-static. cc.gatech.edu/--asb/thesis/

in text citation: (Bruckman, 1997)

\section{Journal article with No DOI}

Bourkhis, K., and Nabi, M. S. (2013). Islamic and conventional banks' soundness during the 2007-2008 financial crisis. Journal Metrics, 22(2), 68-77.

in-text citation: (Bourkhis \& Nabi, 2013).

\section{Journal article with DOI}

Ichwan, M. (2012). The Local Politics Of Orthodoxy: The Majelis Ulama Indonesia in the Post-New Order Banten. Journal Of Indonesian Islam, 6(1), 166-194. doi:http://dx.doi.org/10.15642/JIIS.2012.6.1.166-194

In text citation : (Ichwan, 2012)

\section{Abstract as citation}

Hasan, N. (2012). Islamist Party, Electoral Politics And Da'wah Mobilization Among Youth : The Prosperous Justice Party (PKS) in Indonesia. Journal of Indonesian Islam, 6(1), 17-47. Abstract from http:// jiis.uinsby.ac.id/index.php/jiis/article/view/97

in text citation : (Hasan, 2012)

\section{Mass media article}

Sahal, Akhmad (2014, March 2). Kiai Sahal dan Realisme Fikih.Tempo Magazine, p. 120.

in text citation : (Sahal, 2014) 


\section{Research report}

Fisher, B. S., Cullen, F. T., \& Turner, M. G. (2000). The Sexual Victimization of College Women. Research Report.

in text citation : (Fisher, Cullen, Turner, 2000)

\section{Monograph}

Routray, Bibhu Prasad (2013), National Security Decision-Making in India (RSIS Monograph No. 27). Singapura: Rajaratnam School of International Studies.

in text citation : (Routray, 2013)

\section{Proceeding article}

Sudibyakto, Hizbaron, D.R., \& Jati, R (Ed.) (2009), Proceeding International Seminar Disaster Theory, Research and Policy. International seminar held by Sekolah Pascasarjana, Universitas Gajahmada, Yogyakarta, 8-9 Desember 2009.

in text citation : (sudibyakto and Jati, 2009)

\section{Paper conference/seminar/symposium}

Janutama, Herman Sinung (2011). "Kraton dan Hubungan Antar Agama." Paper presented in Seminar Kraton dan Panatagama held by Center for the Study of Islam and Social Transformation (CISForm), Yogyakarta, 17 November.

in text citation :(Janutama, 2011)

\section{Online article in web}

Shiva, (2006, February). Bioethics: A Third World Issue. Native-web. Diperoleh dari http://www.nativeweb.org/ pages/legal/shiva.html

in text citation : (Shiva, 2006) 


\section{Online research report}

Kessy, S. S. A., \& Urio, F M. (2006). The contribution of microfinance institutions to poverty reduction in Tanzania (Research Report No. 06.3). Retrieved from Research on Poverty Alleviation website: http://www. repoa.or.tz /documents_storage/Publications/Reports/06.3_Kessy_and_ Urio.pcif

in text citation : (kessy and urion, 2006)

\section{Holy book}

Qur an, $2(25)$

In text citation : (Q. al-Baqarah 2:25).

\section{Encyclopaedia}

Graycar, Adam (1992). Social Welfare Policy. Dalam Mary Hawkesworth dan Maurice Kogan (Ed.), Encyclopedia of Government and Politics (Vol. 1). London: Routledge.

in text citation : (Graycar, 1992)

\section{Interview}

Sultan Hamengkubuwono X (interview, 2011, April 19)

in text citation: (Hamengkubuwono, 2011)

\section{Documentary film}

Steijlen, Fridus (2008). A Day in the Life of Indonesia [documentary film, 58 minutes]. Leiden: KITLV Press.

in text citation : (Steijlen, 2008) 
Vol. 3 No. 1, January - April 2018 